\title{
Secondary school mathematics student teachers' causal attribution for success and failure in mathematics
}

\author{
Savaş Baştürk ${ }^{1}$ \\ ${ }^{1}$ Elementary Mathematics Teacher Education, Sinop University, Sinop, Turkey \\ For correspondence: sbasturk@sinop.edu.tr
}

\begin{abstract}
Attribution theory deals with the question of how individuals make judgments and seek to explain how they consider the causes of their behaviours and those of others. Attributions have the potential to affect beliefs, emotions and behaviour. Therefore, attribution theory has significantly contributed to the studies on motivation. This study examined student teachers' causal attributions for success and failure in mathematics. The participants in this study were 28 student teachers in the department of secondary school mathematics education at a public university in the north of Turkey. To collect data, a questionnaire composed of one open-ended question was administered to the student teachers and they were asked to write their opinion about the causes of a student's failure and success in mathematics. Student teachers wrote and submitted a reflection of one or two pages. Their written responses were examined and qualitatively analysed to determine the common themes by means of qualitative analysis software. The results have revealed that the student teachers categorize four causes to attribute for the students' failure in mathematics: causes originating from students, causes originating from teaching and learning methods, causes originating due to the nature of mathematics itself and physical causes. The most frequent cause mentioned by the student teachers was innate math talent, an internal, stable and uncontrollable cause.
\end{abstract}

Keywords: causal attribution theory; student teachers; mathematics education; teacher training.

\section{Introduction}

By nature, people are interested in the events occurring around them and therefore they often seek to find the answers to the question "why?" especially when they encounter something unexpected or unpleasant (Försterling, 2001; Wong \& Weiner, 1981). This interrogation leads us to attribute some causes to these events. Thus, attributions are related to how we perceive the causes of outcomes. Is the process of assigning causes governed by rules or not? Do attributions change from one individual to another or from one outcome to another? What do attributions affect? Which relations are there between attributions and expectations? All of these questions are important and included in the scope of studies on attribution theory.

Attribution theory deals with the question of how individuals make judgments and seek to explain how they consider the causes of their behaviours and those of others (Weiner, 1985, 1992, 2000, 2004). Attributions have the potential to affect beliefs, emotions and behaviour. Therefore, attribution theory has significantly contributed to the studies on motivation (Graham \& Williams, 2009; Schunk \& Zimmerman, 2008). There are different dimensions of causal attributions. People may think that outcomes happen independently or dependently of how they behave. This is related to the internality-externality dimension of causal attributions and it is called as the locus of control (internal or external). Based on the hypothesis that expectancy beliefs have an impact on behaviours, it can be asserted that the locus of control affects students' achievement. Students who accept their role in their successes and failures should be more motivated to participate in academics tasks; they expend effort 
and persist more than those who completely or partly disaffirm the effect of their behaviours on outcomes (Lefcourt, 1976; Phares, 1976; Shores \& Smith, 2010).

At the same time, a causal attribution may vary or not over time. The degree of an individual's effort may temporarily become different. Luck is also changeable. One moment our luck can be with us another moment it may leave us. However, task difficulty is relatively stable and task conditions almost always remain the same. This feature of causal attributions is included in the stability dimension (stable or unstable).

The two dimensions above are developed by Weiner et al. (1971) based on the studies of Heider (1958) and Rotter (1966). Later, Weiner (1979) added a third dimension. It is controllability. This dimension addresses whether the attribution is personally or externally controllable or uncontrollable. An individual may control his/her effort into a task; therefore the effort is a controllable cause. However, being ill is not something under the control of individuals. They may not choose to be ill or not. In the achievement settings, ability, effort, task difficulty, and luck are often used by students to explain their successes and failures (Weiner et al., 1971). Surely, attributions used by students are not just these, but these are more popular (Schunk, 2012). Therefore, there are also other attributions identified in the research, such as other people (teacher, students or family), textbook, non-correlation between maths and everyday life, mood, fatigue, illness, personality, and physical appearance (Baştürk \& Yavuz, 2010; Baştürk, 2012; Frieze, 1980; Frieze, Francis, \& Hanusa, 1983).

Attributions inevitably affect individuals. They can have impact on expectations for future successes, achievement behaviours, and emotional reactions (Graham \& Williams, 2009; Weiner, 1992, 2000). Therefore, this makes attributions important for motivation, consequently for teaching and learning. Different dimensions have different effects. For example, it is difficult to expect students, who consider their control over academic achievement as little, to have high hopes for success and high motivation to be successful (Licht \& Kistner, 1986). In the face of failure, students who perceive themselves as having low ability, experience difficulties in classroom engagement (Glasgow, Dornbush, Troyer, \& Ritter, 1997). The locus dimension can influence affective reactions. Attributing an outcome to internal causes may lead an individual to experience greater pride in the case of success or greater shame in the case of failure (Weiner, 1992). It can also be hypothesized that the stability dimension has an impact on expectancy of success. As long as task conditions do not change much, students who attribute outcomes to stable causes such as high ability, low task difficulty may demonstrate higher expectations for subsequent successes than those who explain them with unstable causes such as immediate effort and luck (Schunk, 2012).

On the other hand, the question of whether attributions change according to individual differences has occupied many researchers for a long time. Since there is no clear-cut conclusion, this is still an open-ended question. Some studies revealed that gender (Bong \& Clark, 1999; Meece, 2002; Meece \& Courtney, 1992), or ethnic background (Friend \& Neale, 1972; Weiner \& Peter, 1973) change attributions. However, there are also other studies which do not seem to support these results (e.g., Diener \& Dweck, 1978; Dweck \& Repucci, 1973; Graham, 1994; Graham \& Long, 1986; Lehman, 1987; Pajares \& Schunk, 2001). In fact, the studies identifying differences are methodologically criticized because they did not consider some variables such as socioeconomic development (Graham, 1991).

In order to increase students' success in mathematics, it is important to determine causes who lead students to fall behind academically. In this subject, attributions and their dimensions offer teachers a good starting point (Shores \& Smith, 2010). Mathematics is perceived as the most difficult lesson by most of the people. Therefore, attributions have a particular importance for teachers and math education researchers. Shores and Smith (2010), in their literature review study on attribution studies 
in mathematics from 1974 through 2008, identified three studies since 2000 and underlined the necessity of continuing studies on attribution that is vital to students' success in mathematics. More specifically, to increase the success of mathematics students, especially the low achievers' success, the fact that researchers and (student) teachers understand the nature of causes which lead these students to experience difficulties is very important. Surely, the first step of this attempt is to determine their attributions to success and/or failure and their consideration of actual success. Although the recent studies on this subject address what attribution is and the causes of success and/or failure, they are not sufficient to provide a regular classroom teacher with practical information. It is therefore important to design studies aiming at investigating whether or not (student) teachers recognize their own attributions and how these affect their mathematics teaching (Shores \& Smith, 2010). Recognizing student attributions can help student teachers to promote their students' success and to understand the causes behind their failure.

The purpose of this study was to examine the mathematics student teachers' causal attributions of success and failure in mathematics. The study was conducted in Turkey, using a research group of Turkish student teachers. In our selection of this research group, there are many reasons as follows: firstly, there is no empirical data in the literature describing the attributions of Turkish mathematics student teachers, in contrast to other countries' literature. As rightly questioned by some researchers such as Cao and Bishop (2001), although causal attribution theory offers an adequate framework to classify attribution factors, the issues of differentiation of attributions are open-ended. Cultural factors, as well as personal factors, are also effective in the differences, when people have different cultural backgrounds.

People's opinions, beliefs and values may change with regard to their own cultural groups. As indicated by Pan, Chaffee, Chu, and Ju (1994), opinions, beliefs and values may act as "behaviour principles that function as standards of desirable ends and of the means to achieve those ends" (p. 20). Therefore, as Turkish student teachers culturally have different beliefs and values from their peers from other countries, their ways of making judgments such as attribution may be different and need to be investigated.

Another reason for this study is that the education the student teachers are provided with, should enhance positive attitudes and opinions about their profession and prospective students (Baştürk, 2009; Johnson \& Howell, 2005; Senemoğlu \& Özçelik, 1989). As already mentioned, the type of teachers' causal attributions of student success and failure is very important and plays a formative role in reporting behaviour toward the failing or low-achieving student (Georgiou, Christou, Stavrinides \& Panaoura, 2002). Thus, we believe that the results of the present study will contribute to consider with which perspectives the student teachers graduate from the faculty of education at the end of a four-year education.Manuscripts must be submitted in electronic format as Microsoft Word document file.

\section{Method}

The study uses a survey research design to diagnose the secondary school mathematics student teachers' causal attributions for success and failure in mathematics. In comparison to the experimental research, the survey research designs ask researchers not to manipulate the conditions experimentally. Thus, it is not expected from them to explain the cause and effect such as experimental researchers (Creswell, 2012). Thus, this study investigates what student teachers think about the causes of students' success and failure in mathematics without being influenced them in any way. 


\section{The Participants and setting}

The study participants were 28 student teachers who were enrolled in the department of secondary school mathematics education in the faculty of education of a state university in Turkey. Data were collected during their last semester. There were 9 females and 19 males ranging from the age 21 to 23 with an average age of 22 .

Mathematics Teacher Education Program in Turkey last five years or ten semesters and aims to train mathematics teachers for high schools. In first seven semesters, student teachers should take some courses such as music, foreign language, science and some mathematics courses such as calculus, linear algebra, abstract mathematics. The rest of the semesters focus on education and math education. For example, special instruction methods, development and learning, planning and evaluation of instruction, school experience, teaching practicum courses are among the courses taken in this period. As a result, it can be asserted that the participant student teachers have suitable background and experience to participate in such a study.

Data collection and analysis

To collect data, a questionnaire composed of one open-ended question was administered to the student teachers. To answer the question, the participants were asked to select the student with the lowest performance in math class as a point of reference. The student's performance should be at a level to consider as unacceptable for the particular grade. The student teachers were also asked not to refer to students with a diagnosed mental retardation, sensory handicaps, or syndromes. Finally, they were asked to give details about their reasons of this student's failure and success in mathematics.

According to Jackson and Trochim (2002), data obtained from open-ended questions are impressive because they can provide "rich description of respondent reality at a relatively low cost to the researcher" (p. 307). Open-ended survey questions can be responded with greater anonymity and in general produce more authentic responses than interviews or focus groups (Erickson \& Kaplan, 2000). Furthermore, compared with closed-ended questions they are able to elicit alternative explanations and different responses (Miles \& Huberman, 1994; Tashakkori \& Teddlie, 1998). As all data collection and analysis methods have limitations, there are some drawbacks of open-ended questions such as having non-responses, spending more time for analysis, validity and interrater reliability among raters (Seidel \& Kelle, 1995).

Student teachers wrote and submitted a one or two pages reflection of their opinions. They were invited to write a pseudonym on their copy instead of their own name to guarantee the genuineness of responses. The written responses were examined and qualitatively analysed for the common themes by means of a qualitative analysis software (Nvivo8). In the analysis, firstly student teachers' responses were classified and then categories and sub-categories were determined. These categories were always compared with each other and after that common categories were determined (Creswell, 1998). By taking into account the relationships between them, categories and sub-categories were modelled. Frequencies were calculated and thus qualitative data were transformed into quantitative. To determine the inter-judge reliability of the open-ended question, data and categories were examined by the researcher and two other experts from the department of secondary school mathematics teacher education. Disagreements among the experts were solved through discussions and a great common agreement was provided on categories and coding (Lincoln \& Guba, 1985).

\section{Results}

The results of the analysis of the student teachers' responses show that they attribute four categories of causes to explain the students' failure in mathematics which is listed as: causes resulting from students (26 student teachers [STs]), causes resulting from teaching and learning methods (24 STs), reasons due to the nature of mathematics itself (9 STs) and physical causes (4 STs). 
Student teachers' causal attributions related to student

26 student teachers expressed the causal attributions of success and failure in mathematics resulting from the student her/himself. As seen in Figure 1, the causes are categorised into three main categories as follows: innate math talents (17 STs), loving and being interested in mathematics (14 STs) and properties that are not innate (12 STs).

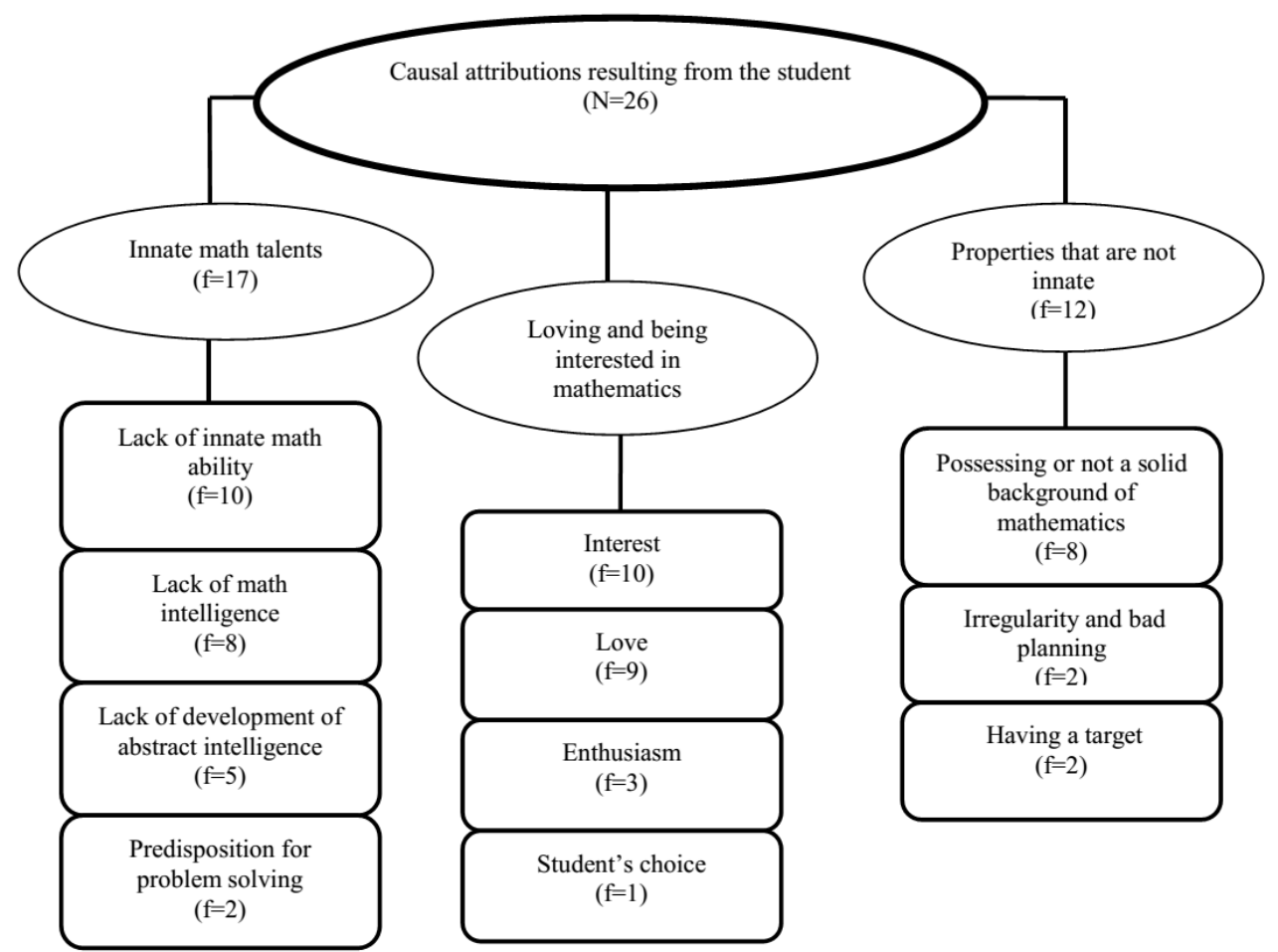

Figure 1. Student teachers' causal attribution related to students

The following extracts were typical of such comments:

(...) In order to be successful in mathematics lesson, the students should have innate math ability. While some people spent more effort to understand a simple thing in mathematics, others can easily solve many difficult problems, because everybody has different capabilities. Thus, it is not reasonable to wait that everybody succeeds in mathematics. Every voice is not suitable to sing; similarly everybody cannot succeed in mathematics (ST22).

(...) Student interest, capability and willingness to learn are important issues. You cannot teach a student what s/he does not want to learn. The things taught in this way are forgotten quickly. That is, memorization takes the place of learning. On the other hand, difficulty of topic to be taught is another cause. As a result, personal effort is very important (ST17).

(...) In high school we use what we learned in elementary and middle school and at university what we learned in high school. It is the same for previous classes. For example, it is impossible for a student to fully understand the functions without having understood and interiorized sets (...). To overcome this obstacle, it is necessary to seriously check students' mathematics comprehension in every class hour to see whether they received the required knowledge and skills (ST6).

In the first comment, the student teacher highlighted the importance of innate math talent. In his opinion, different students have different levels of mathematical capability. He strengthened his opinion by an analogy between the capability of singing and mathematical intelligence. The second comment was very rich in the context of expressing causes of math success or failure. So, the student 
teacher indicated that a student should have willingness, capability of and interest in learning (mathematics) to succeed in mathematics. She underlined that it was very difficult to teach someone what s/he didn't want to learn. In her opinion, without willingness to learn the students could only memorize the subjects but they would never learn them. Moreover, the difficulty of the task and the students' personal effort were the other causes attributed by the student teacher. The third comment indicated that topics to be taught in mathematics were strictly related to the previously taught contents. Therefore, if the students did not understand the sets, it was unlikely for them to master the functions completely. At the same time, the student teacher recommended all the teachers to always check whether the students had understood the topic in question.

As a result, it can be asserted that innate math talent is a crucial argument to explain the students' success or failure in mathematics. Some people have it and some do not. Another important cause mentioned by the student teachers in this category is the lack of a strong math background. On the other hand, the student teachers also considered not loving maths and not being interested in mathematics as a barrier to student success in mathematics.

Student Teachers' causal attributions related to the nature of mathematics itself

Figure 2 reveals that there were 9 student teachers who mentioned causal attributions resulting from the nature of mathematics itself. These can be divided into four categories: the cumulative aspect of mathematics (5 STs), not knowing how to study for math (3 STs), the abstract aspect of maths and little liaison of maths with everyday life (2 STs) and the complexity and multiplicity of topics in mathematics (2 STs).

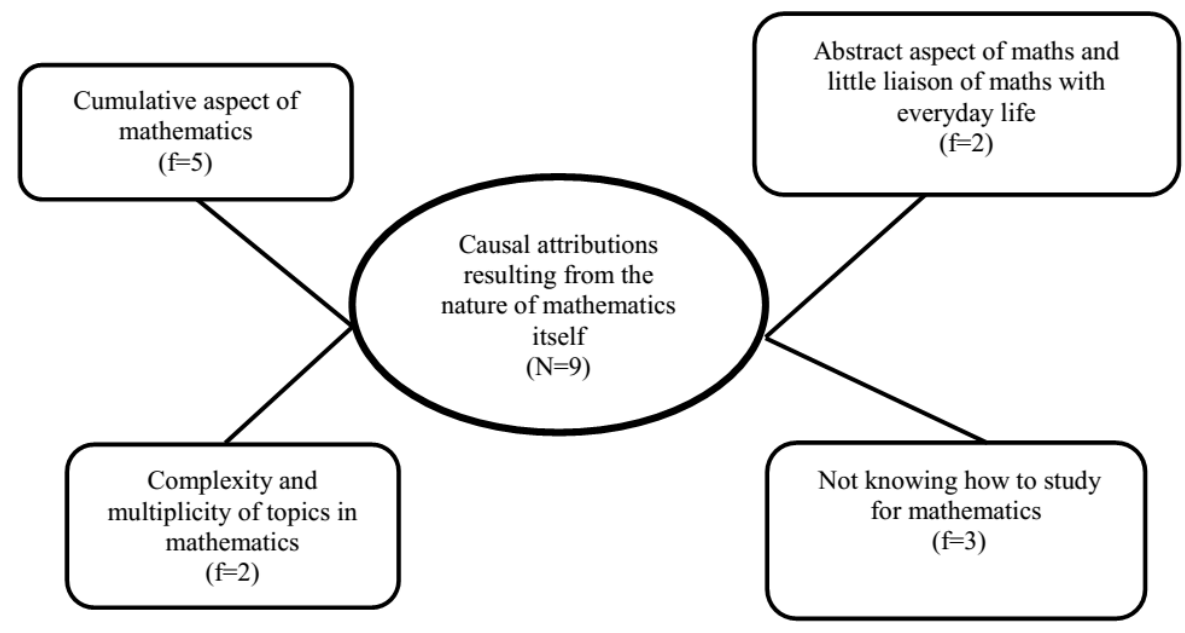

Figure 2. Student teachers' causal attributions related to the nature of mathematics itself

All this was reflected in the following extracts:

(...) Mathematics is a cumulative lesson. Therefore, if a student missed one hour of a lesson, s/he may feel unsuccessful and start to be uninterested in the lesson I believe, to be more successful in maths more individual education is necessary (ST23).

(...) I believe mathematics is not the act of keeping in mind but the ability of associating. I cannot understand the meaning of a formula if I do not know how it is produced. (...) I believe that there is a common misjudgement about mathematics which reduces it only to a subject area consisting of only numbers. When I advise the low achiever students in maths, to read books for developing their understanding capability, they are surprised (ST21).

(...) In my opinion, another reason of failure in maths is that students do not know how to study for it. Many students believe that mathematics can be studied by simply reading relevant concepts 
and knowledge so they neglect the problem solving and application. Therefore, they cannot establish their mathematics knowledge as required (ST25).

(...) Generally, associating mathematical concepts with everyday life is very difficult. I think the lack of mathematics capability is also one of the important causes. Sometimes when solving problems, students face difficulties due to the lack of knowledge. This might also raise math anxiety. In mathematics, there are a lot of topics some of which very detailed and understanding some others is very difficult for a human mind, such as infinite sets, negative numbers and complex numbers (ST12).

The first comment underlined that the cumulative aspect of mathematics. Missing some hours of the lesson, may cause some problems such as indifference and dislike for students. This leads students to fail in mathematics. He also associates being more successful in maths with more individual education. In the second comment, contrary to memorization, associative learning is put forward. In her opinion, formula centred learning causes the students to establish the idea that maths only consists of numbers. In the next comment, the student teacher perceived the lack of methodological knowledge to study for mathematics as a cause of failure. Thus, she stated that as many students couldn't know how to study for it, they failed in mathematics. Studying mathematics was to solve problems, but not to simply revise presented concepts and knowledge. In the last comment, many causes of math failure were mentioned: poor interrelation between the math concepts and everyday life, lack of mathematics capability, lack of knowledge in problem-solving process, and complexity and multiplicity of mathematical concepts to be taught.

In summary, the student teachers' causal attributions highlighted that the cumulative aspect of mathematics was important. The students' weaknesses in the previous topics prevent them from understanding the followings topics and lead students' failure. Not knowing how to study for mathematics, the abstractness and the distant relation of mathematics to everyday life, and the abundance and sophistication of math topics were other causes mentioned.

\section{Student teachers' causal attributions related to teaching and learning of mathematics}

There were 24 student teachers who expressed some causal attributions related to the teaching and learning of mathematics. These causes can be grouped into three categories: causes resulting from teachers (17 STs), teaching methodology (14 STs) and educational system (4 STs). 


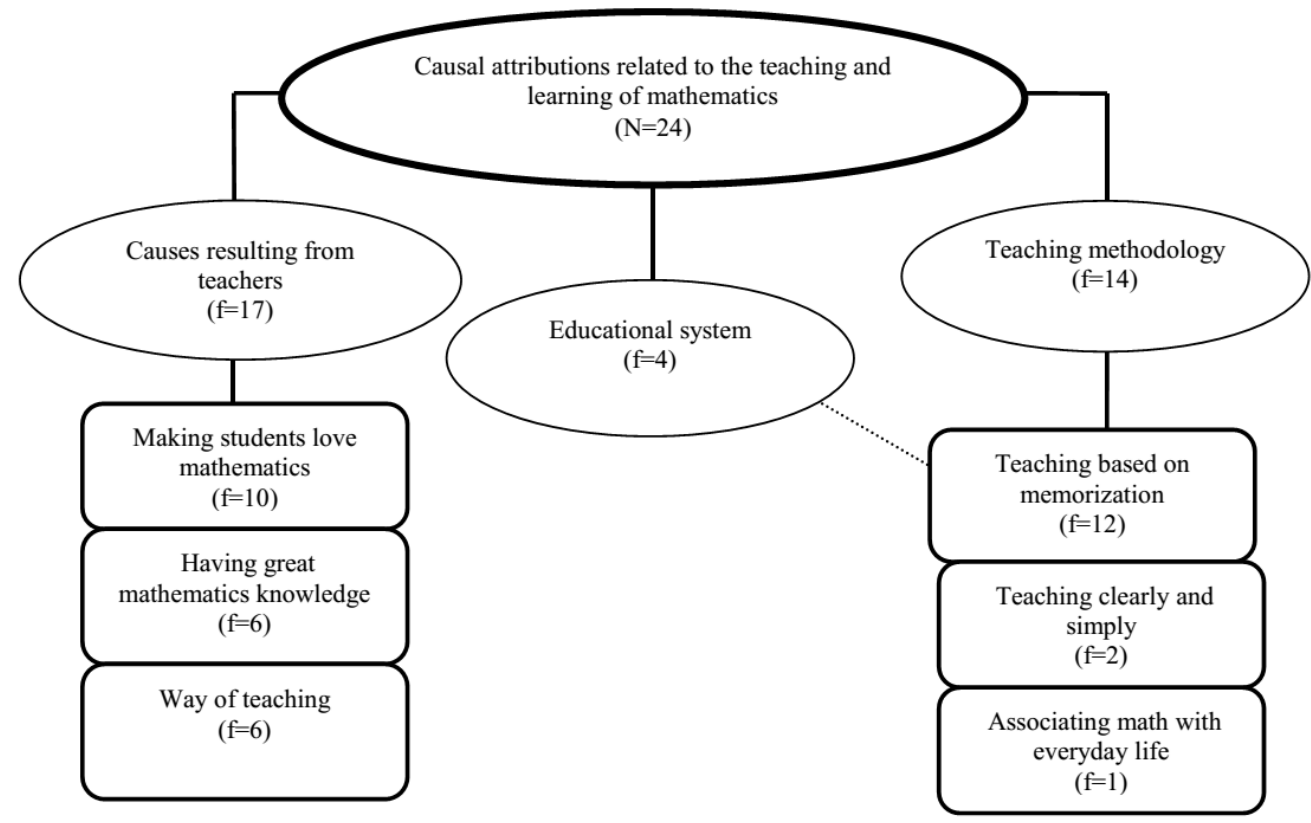

Figure 3. Student teachers' causal attributions related to teaching and learning of mathematics

These following extracts will clarify the student teachers' points:

(...) Teachers have a major role, because until now I have seen that people who do not like mathematics also do not like their mathematics teachers. Therefore, in my courses, I try to make my students love me before they love mathematics. Surely, making students love the teacher and mathematics is not enough at all. At the same time, we should teach mathematics to students in an easy and clear way. Otherwise, the students might fail again (ST14).

(...) Some teacher features, especially effort, play a significant role in understanding mathematical subjects. Teacher should have thorough theoretical knowledge on topics. Of course, this is not enough on its own. This knowledge should also be transferred to the students in a comprehensible way. Dialogues and relationships between student and teacher are quite important (ST17).

(...) Mathematics is perceived and reflected as a lesson of memorization, but not that of logic and reasoning. When students are told that $24=16$, it means nothing to them. Therefore, they begin to memorize it. However, if concepts are presented more clearly, it will be easy to learn mathematics. The purpose of mathematics should not be only making some calculations but developing our mind by means of them. That is, in the face of a different problem, students should be able to develop some solutions procedures (ST18).

(...) Mathematics is a process. Passing exams by memorizing in a certain way a few days before the exam, does not mean being successful in mathematics. Our own situation stands as an example. We passed the examination of many maths lessons with $95 \%$ success rate, but we cannot display the same success again (...). As a result, with teaching and learning based on memorization we cannot succeed in mathematics. So, the biggest handicap is that success in exams is viewed as real success (ST2).

In the first comment, the student teacher argued that the teacher played an important role to make students love mathematics. He hypothesized that if the students love their math teachers, they will also love mathematics. Another cause was the clarity of teaching. The next comment described many causes of success and failure related to some teacher characteristics such as effort to teach, lack of 
subject matter knowledge and pedagogical content knowledge and relationship between teacher and student. In the third comment, the student teacher criticised teaching mathematics through memorization. She highlighted the importance of meaningful mathematics teaching and indicated that otherwise some misbeliefs about mathematics can be strengthened: mathematics is a lesson which consists of only numbers and based on memorization. To overcome these difficulties, she suggested a teaching based on real life problems. The last comment identified what the effective success was in mathematics. In his opinion, being successful in an exam did not mean that the students completely learned the topics as most of the students passed the exams by memorizing the subjects as a few days before the exam.

In conclusion, the student teachers put the teacher in the centre of the causes related to teaching and learning of mathematics. So, the teacher should make student love maths, to have in depth subject matter knowledge and to know ways of lecturing. On the other hand, some student teachers accused the actual Turkish educational system since it encourages "rote learning". Clarity and simplicity of teaching were also important for some student teachers since they had the potential to cause success or failure.

\section{Student teachers' causal attributions related to family and social environment}

Figure 4 reveals causal attributions resulting from the family and social environment. There are 12 causes mentioned by the student teachers in this category. They can be classified into five different categories as follows: negative attitude of the social environment towards mathematics (5 STs), absence of someone at home to help the child (3 STs), lack of infrastructure at school (3 STs), family's interest in the child (2 STs) and economical causes (1 ST).

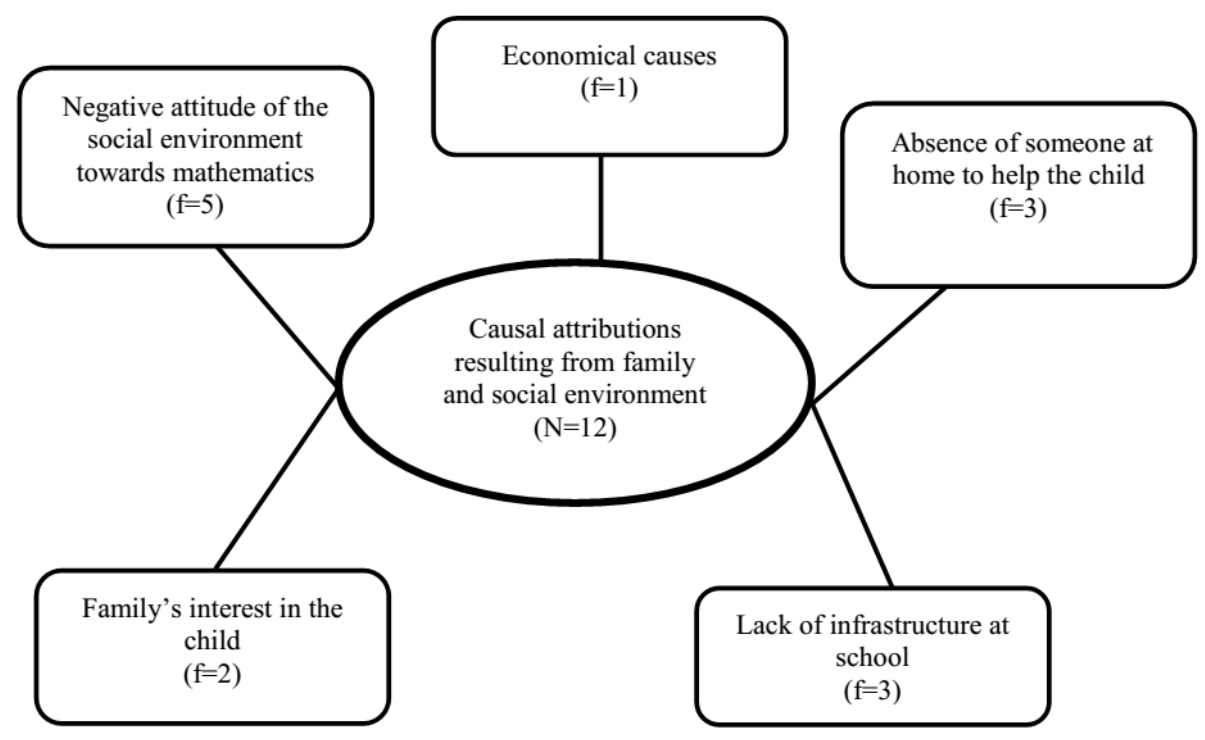

Figure 4. Student teachers' causal attributions related to family and social environment

The following comments illustrated this type of causes:

(...) Prejudices against mathematics resulting from students' social environment play an important role in their success or failure in mathematics. Therefore, the students who were exposed to this type of prejudices will probably begin to learn mathematics with math anxiety. Furthermore, students' psychological situation, familial status, for example, having a conscious family also have an impact on developing positive attitudes toward mathematics (ST8). 
(...) Even though there are suitable environment and great intelligence, if the person does not exert a good effort, s/he will fail. If a student only comes to class because of the attendance policy, if s/he studies only to succeed them and does not study further to add up to the things done in the classroom, s/he may appear to be successful at school but will fail the examination of life (ST28).

(...) This problem is primarily caused by the social environment. Some discourses such as "mathematics is very hard. Everyone cannot be successful at mathematics" lead a child to have negative ideas about mathematics. In contrast, if at home there is a person who can help student doing homework (such as big brother or sister etc.) at home, this will positively affect math success (ST1).

In the first comment, the main causal attribution of success or failure in mathematics was negative attitudes toward mathematics from social environment. The student teacher hypothesized that prejudices against mathematics resulting from their social environment may cause students to start math learning with anxiety. Furthermore, she also stated psychological situation and familial status as causes. The second comment emphasised the need of students' effort. On the other hand, studying only to pass lessons were criticized and attributed as a cause of failure by the student teacher. In the third comment, in addition to the cause of negative talks about mathematics from social environment, the student teacher mentioned the absence of someone who can help student doing homework.

As a result, to explain students' success or failure, the student teachers stated that the negative attitudes toward mathematics were viewed as one of the important causes related to social environment. Furthermore, students' deprivation of the assistance or interest of an adult, lack of infrastructure at school and economical causes were also indicated by some student teachers as this type of causes.

\section{Discussion}

This study examined mathematics student teachers' causal attributions of success and failure in mathematics. As they have potential impact on students' own attributions through teacher behaviour, causes attributed by (student) teachers to explain their students' success and failure are very crucial (Fennema, Peterson, Carpenter, \& Lubinski, 1990). Moreover, attributions play a major role in the forming of teachers' expectancies for students' future academic success (Clarkson \& Leder, 1984; Peterson \& Barger, 1985). In this context, we conducted this research with 28 student teachers and obtained the following results:

When regarding to their causal attributions related to the student, we considered that the student teachers participating in this study suggested three causes which were internal, stable and uncontrollable. This was lack of innate math talent or intelligence. There was a significant number of the student teachers who believed that math ability is innate and among God-given talents. Some students have this ability and some do not. In the context of the causal attribution theory and Dweck's (2000, 2006) mindset theory, this type of beliefs can be accepted as quite dangerous. As we discussed the first one in detail, we want to focus on the second one very briefly. According to Dweck's mindset theory, in students' response to challenge their mindset or their belief that abilities can be developed or are innate, play a mediator role. If people consider intelligence to be innate, they less likely tend to select challenging tasks due to the unwillingness of disconfirming their intelligence before others. Conversely, in the case of believing that intelligence is malleable and can be developed, people tend to take more challenging materials since they believe that how they deal with the task at hand does not imply something about their overall intelligence. Consequently, the first type of people seems to have helpless responses to challenging material, while the second type appears to have responses to the challenging material. 
As already indicated, innate math talent is an internal, uncontrollable and unchangeable cause. When outcomes are explained by internal causes rather than by external ones, the individual experiences greater pride after succeeding and greater shame after failing (Schunk, 2012; Weiner, 1992). The sense of controllability plays a stimulating role in being involved in the academic affairs of the individual and showing more effort and patience towards hard work (Bandura, 1986; Dweck \& Bempechat, 1983; Monty \& Perlmuter 1987; Schunk \& Zimmerman, 2006; Wang, 1983). Licht and Kistner (1986) underline that students considering their control over academic outcomes to be little hold low expectations for success and exhibit low motivation to succeed. The results of some studies seem to support this hypothesis, e.g., students who explain their failures with low ability (an uncontrollable cause) show lower classroom engagement up to a year later (Glasgow, Dornbusch, Troyer, Steinberg, \& Ritter, 1997). Thus, if the teacher attributes failure to the lack of innate talent, it is not difficult to suppose how the situation is serious for students who think about themselves in the same way. Teachers (or student teachers) who are proponents of innate math talent would not have enough effort to develop the success of students considered as untalented by them.

Not loving and not being interested in mathematics were also viewed by the student teachers as barriers to succeed in mathematics by the student teachers. By underlining the belief that if students love their math teacher, they will also love math, some student teachers gave the biggest role to math teachers in the establishment of this love and interest. Lack of a strong math background, lack of a target and irregularity and bad planning were other causes related to the students. All of them are internal, controllable and unstable. Indicated by the student teachers as well, students' attitudes towards mathematics can be altered by the teacher. In the same way, by taking some precautions, problems related to math background can be overcome in the long run. In line with these results, in his study conducted with primary student teachers, Baştürk (2012) identified that one of the attributions most frequently selected by the participants was lack of math background. This shows that the problem is not restricted to the research group of this study.

Math topics have a spiral structure compared to the other lessons. A student cannot fully acquire a mathematical concept if s/he does not have the prerequisite knowledge. However, in other lessons, for instance in history, the student may understand the contemporary period without knowing the ancient history. In general, topics in math curriculum have a permanent structure and their content increases with the progression of classes. It is difficult to expect a student to understand multiplication without understanding addition. Students' weaknesses resulting from background create important problems in their mathematics learning process. Thus, the student teachers' sensitivity on this subject is very reasonable.

In line with the cause of lack of background, the cumulative aspect of mathematics was considered as an important cause by the student teachers. It is an external, stable and uncontrollable cause. These three dimensions give us the impression that we are exposed to a problem which can be overcome. However, in our educational system, the repetition of class has almost become impossible and teachers cannot devote sufficient time to students due to the density of curriculum and the large size of classes. These conditions complicate teacher's search for solutions of problems of background or cumulative aspect of maths (Baştürk, 2012). On the other hand, we considered that some student teachers mentioned lack of knowing how to study for mathematics, the abstractness and distant relation of mathematics to everyday life, and the abundance and sophistication of math topics as a cause of student's success or failure. Certainly, all of these causes are important, although they were stated by few participants. But, we believe that the association of mathematics with everyday life should especially be discussed. For many (student) teachers, it exists like a myth. Maybe it is reasonable in elementary or middle school. But in high grades the association of everyday life can be difficult or too ordinary. Many student teachers think that they associate, for instance, the concept of limit with everyday life, by giving examples such as the limit of a credit card or speed. However, the 
concept of limit in math does not exactly coincide with that of everyday life (Dönmez, 2009; Jordaan, 2005; Williams, 1991). Instead of that, at the point where it is indefinite a rational function can be examined and so the inability of function concept and the necessity of limit concept can be underlined.

According to the student teachers, the role of teacher is not negligible in students' math success and failure. They believe that it is important that teacher make students love math and they have great subject matter knowledge. In addition, teachers should know ways of teaching. According to Schunk (2012), some students generally believe they have little control over their academic successes and failures but this attitude may positively change when the teacher and the peers are helpful. Consequently, the fact that students like the lesson is very important, and it is good that the student teachers are aware of this.

On the other hand, some student teachers blame the actual Turkish educational system for "rote learning" by Mayer (2002) underlines that promoting retention and transfer are two of the most important educational goals. Retention asks student to recall material at a later time in the same way it was presented during instruction. Transfer asks student to use what $\mathrm{s} /$ he has learned in new situations such as solving new problems, answering new questions, facilitating to learn a new subject matter (Mayer \& Wittrock, 1996). Thus, there is a nuance between them: remembering is important for both but transfer also requires to make sense and have the ability of using what was learned (Bransford, Brown, \& Cocking, 1999; Haskell, 2001). If the didactic contract between the teacher and student is established only by considering the retention dimension, teachers do not probably challenge her/him with transfer situations (Brousseau, 1988). When student encounters them elsewhere, for instance, in a textbook or a national exam, failure becomes inevitable. Therefore, it is possible to say that the student teachers are right in considering rote learning as a failure cause.

Regarding causal attributions related to family and social environment, the student teachers believed that negative attitudes towards maths from social environment were one of the most important causes to be considered in this subject. According to them, the negative or positive dialogues had a potential to negatively or positively influence students. Furthermore, they indicated lack of the assistance or interest of an adult, lack of infrastructure in school and economical causes among this type of causes. Even though some researchers believe that it is much exaggerated (Harris, 1998), there is a strong common sense that the family environment has a very important role in the child's development and learning. However, the conducted researches day to day continue to support the existence of this effect (Collins, Maccoby, Steinberg, Hetherington, \& Bornstein, 2000; Masten \& Coatsworth, 1998).

\section{Conclusion and Recommendations}

As a result, this study allowed us to consider the student teachers' causal attributions of success and failure in mathematics, but this was restricted only to their beliefs and so their written responses. Thus, further research is needed to focus on how these beliefs are reflected by (student) teachers in practice. The present study was designed with a qualitative approach. Therefore, a limited number of student teachers were included in the research and the aim was to try to reveal an image rather than to reach generalizations about the research problem. The researches designed with a quantitative approach can examine the problem in a more detailed way and it may reveal more general results.

As already mentioned, the effort of changing attributions have a potential to change self-accusation circle and help prevent some possible failures and low performance in future that can occur in other attempts (Wilson, Damiani, \& Shelton, 2002). It is well known in teacher training area that positive changes in teachers' beliefs will positively influence their practice (Fennema \& Franke, 1992). Thus, in faculties of educations, through some courses such as educational psychology, attribution theory can 
be presented in detail to positively change or develop student teachers' causal attributions of failure or success in maths.

\section{Acknowledgements}

An early version of this research was presented in The 6th International Conference on Teacher Education. The author would like to thank the student teachers who participated in this study for their collaboration.

\section{References}

Bandura, A. (1986). Social foundations of thought and action: a social cognitive theory. Englewood Cliffs, NJ: Prentice Hall.

Baştürk, S. (2009). Ortaöğretim matematik öğretmen adaylarına göre fen edebiyat fakültelerindeki alan eğitimi [Perspectives of student teachers of secondary mathematics education on mathematics teaching in faculty of arts and science]. Inön ̈̈ Üniversitesi Eğitim Fakültesi Dergisi [Inonu University Journal of the Faculty of Education], 10(3), 137-160.

Baştürk, S. (2012). Sınıf öğretmenlerinin öğrencilerin matematik dersindeki başarı ya da başarısızlı̆̆a atfettikleri nedenler [Classroom teachers' causal attributions of student success or failure on mathematics]. Mehmet Akif Ersoy Üniversitesi Sosyal Bilimler Enstitüsü Dergisi [Journal of Mehmet Akif Ersoy Social Science Institute], 4(7), 105-118.

Baştürk, S., ve Yavuz, I. (2010). Investigating causal attributions of success and failure on mathematics instructions of students in Turkish high schools. Procedia-Social and Behavioral Sciences, 2(2), 1940-1943.

Bong, M., \& Clark, R. (1999). Comparisons between self- concept and self-efficacy in academic motivation research. Educational Psychologist, 34, 139-154.

Bransford, J.D., Brown, A.L., \& Cocking, R. (1999). How people learn: Brain, mind, experience, and school. Washington, DC: National Academy Press.

Brousseau, G. (1988). Le contrat didactique: Le milieu [The didatic contract: The environment]. Recherches en Didactique des Mathernatiques [Research in Mathematics Education], 9(3), 309-336.

Cao, Z., \& Bishop, A. (2001). Students' attributions of success and failure in mathematics: findings in China and Australia. 24th Annual MERGA Conference, Sydney.

Clarkson, P., \& Leder, G.C. (1984). Causal attributions for success and failure in mathematics: A cross cultural perspective. Educational Studies in Mathematics, 15, 413-422.

Collins, W. A., Maccoby, E. E., Steinberg, L., Hetherington, E. M., \& Bornstein, M. H. (2000). Contemporary research on parenting: The case for nature and nurture. American Psychologist, 55, 218-232.

Creswell, J. W. (2012). Educational research: Planning, conducting, and evaluating quantitative and qualitative research (4 $4^{\text {th }}$ ed.). Boston, MA: Pearson Education.

Creswell, J.W. (1998). Qualitative inquiry and research design: Choosing among five traditions. Thousand Oaks, CA: Sage.

Diener, C. I., \& Dweck, C. S. (1978). An analysis of learned helplessness: Continuous changes in performance, strategy, and achievement cognitions following failure. Journal of Personality and Social Psychology, 36, 451-462.

Dönmez, G. (2009). Matematik öğretmen adaylarının limit ve süreklilik kavramlarına ilişkin pedagojik alan bilgilerinin değerlendirilmesi [Assessment of pre-service mathematics teachers' pedagogical content knowledge about limit and continuity]. Unpublished Master of Science Thesis, Institute of Education Sciences, Marmara University, İstanbul.

Dweck, C. (2000). Self-Theories: Their Role in Motivation, Personality, and Development. New York, NY: Psychology Press.

Dweck, C. (2006). Mindset: The New Psychology of Success. New York, NY: Random House.

Dweck, C. S., \& Repucci, N. D. (1973). Learned helplessness and reinforcement responsibility in children. Journal of Personality and Social Psychology, 25, 109-116.

Dweck, C.S., \& Bempechat, J. (1983). Childrens' theories of intelligence: Consequences for learning. In S.G. Paris, G.M. Olson \& H.W. Stevenson (Eds.), Learning and motivation in the classroom (pp. 239-256). Hillsdale, NJ: Erlbaum.

Erickson, P. I., \& Kaplan, C. P. (2000). Maximizing qualitative responses about smoking in structured interviews. Qualitative Health Research, 10, 829-840.

Fennema, E., \& Franke, M. (1992). Teachers' knowledge and its impact in: D.A. Grouws (Ed) Handbook of Research on Mathematics Teaching and Learning (New York: Macmillan Publishing).

Fennema, E., Peterson, P., Carpenter, T., \& Lubinski, C. (1990). Teachers' attributions and beliefs about girls, boys, and mathematics. Educational Studies in Mathematics, 21, 55-69.

Försterling, F. (2001). Attribution. An introduction to theories, research and applications. UK: Psychology Press.

Forsyth, D. R., \& McMillan, J. H. (1991). Some practical proposals for motivating students. In R. J. Menges \& M. Svinicki (Eds.), Approaching instructional problems through theoretical perspective: New directions for teaching and learning (pp. 53-66). San Francisco: Jossey-Bass.

Friend, R., \& Neale, J. (1972). Children's perceptions of success and failure: An attributional analysis of the effects of race and social class. Developmental Psychology, 7, 124-128.

Frieze, I. H. (1980). Beliefs about success and failure in the classroom. In J. H. McMillan (Ed.), The social psychology of school learning (pp. 39-78). New York: Academic Press.

Frieze, I. H., Francis, W. D., \& Hanusa, B. H. (1983). Defining success in classroom settings. In J. M. Levine \& M. C. Wang (Eds.), Teacher and student perceptions: Implications for learning (pp. 3-28). Hillsdale, NJ: Erlbaum. 
Georgiou, S.N., Christou, C., Stavrinides, P., \& Panaoura, G. (2002). Teacher attributions of student failure and teacher behavior toward the failing student. Psychology in the Schools, 39(5), 583-595.

Glasgow, K. L., Dornbusch, S. M., Troyer, L., Steinberg, L., \& Ritter, P. L. (1997). Parenting styles, adolescents' attributions, and educational outcomes in nine heterogeneous high schools. Child Development, 68, 507-529.

Graham, S. (1991). A review of attribution theory in achievement contexts. Educational Psychology Review, 3, 5-39.

Graham, S. (1994). Motivation in African Americans. Review of Educational Research, 64, 55-117.

Graham, S., \& Long, A. (1986). Race, class, and the attributional process. Journal of Educational Psychology, 78, 4-13.

Graham, S., \& Williams, C. (2009). An attributional approach to motivation in school. In K. R. Wentzel \& A. Wigfield (Eds.), Handbook of motivation at school (pp. 11-33). New York: Routledge.

Harris, J. R. (1998). The nurture assumption: Why children turn out the way they do. New York: Free Press.

Haskell, R.E. (2001). Transfer of learning. San Diego: Academic Press.

Heider, F. (1958). The psychology of interpersonal relations. New York: Wiley.

Jackson, K. M., \& Trochim, W. M. K. (2002). Concept mapping as an alternative approach for the analysis of open-ended survey responses. Organizational Research Methods, 5(4), 307-336. http://doi.org/10.1177/109442802237114

Johnson, M. G., \& Howell, A. (2005). Change in pre-service teacher attitudes toward contemporary issues in education. Retrieved May 20 2009, from ERIC database.

Jordaan, T. (2005). Misconceptions of the limit concept in a mathematics course for engineering students. Unpublished Master of Science Dissertation, University of South Africa.

Lefcourt, H. M. (1976). Locus of control: Current trends in theory and research. Hillsdale, NJ: Erlbaum.

Lehmann, C. H. (1987). The adult mathematics learner: Attitudes, expectations, attributions. Paper presented at the Annual Meeting of the American Educational Research Association, Washington, DC. Retrieved from http://eric.ed.gov/PDFS/ED283680.pdf.

Licht, B. G., \& Kistner, J. A. (1986). Motivational problems of learning-disabled children: Individual differences and their implications for treatment. In J. K. Torgesen \& B. W. L. Wong (Eds.), Psychological and educational perspectives on learning disabilities (pp. 225-255). Orlando: Academic Press.

Lincoln, Y.S., \& Guba, E.G. (1985). Naturalistic inquiry. Newburry Park, CA: Sage.

Masten, A. S., \& Coatsworth, J. D. (1998). The development of competence in favorable and unfavorable environments: Lessons from research on successful children. American Psychologist, 53, 205-220.

Mayer, R.E. (2002). Rote versus meaningful learning. Theory into Practice, 41, 226-232.

Mayer, R.E., \& Wittrock, M.C. (1996). Problem-solving transfer. In D.C. Berliner \& R.C. Calfee (Eds.), Handbook of educational psychology (pp. 47-62). New York: Macmillan.

Meece, J. L. (2002). Child and adolescent development for educators (2nd ed.). New York: McGraw-Hill.

Meece, J. L., \& Courtney, D. P. (1992). Gender differences in students' perceptions: Consequences for achievement-re- lated choices. In D. H. Schunk \& J. L. Meece (Eds.), Student perceptions in the classroom (pp. 209-228). Hillsdale, NJ: Erlbaum.

Miles, M., \& Huberman, M. (1994). Qualitative data analysis: An expanded sourcebook (2nd ed.). Thousand Oaks, CA: Sage.

Monty, R.A., \& Perlmuter, L.C. (1987). Choice, control, and motivation in the young and aged. In M.L. Maehr \& D.A. Kleiber (Eds.), Advances in motivation and achievement (Vol. 5, pp. 99-122). Greenwich, CT: JAI Press.

Pajares, F., \& Schunk, D. H. (2001). Self-beliefs and school success: Self-efficacy, self-concept, and school achievement. In R. J. Riding \& S. G. Rayner (Eds.), Self-perception (pp. 239-265). Westport, CT: Ablex.

Pan, Z., Chaffee, S. H., Chu, G. C., \& Ju, Y. (1994). To see ourselves: Comparing traditional Chinese and American cultural values. Boulder, CO: Westview Press.

Peterson, P.L., \& Barger, S.A. (1985). Attribution theory and teacher expectancy. In J.B. Dusek, F.C. Hall, \& W.J. Meyer (Eds.), Teacher expectancies. Hillsdale, NJ: Erlbaum.

Phares, E. J. (1976). Locus of control in personality. Morristown, NJ: General Learning Press.

Rotter, J. B. (1966). Generalized expectancies for internal versus external control of reinforcement. Psychological Monographs, $80(1), 1-28$.

Schunk, D. H. (2012). Learning theories: An educational perspective (6 $6^{\text {th }}$ ed.). Boston: Pearson.

Schunk, D. H., \& Zimmerman, B. J. (Eds.) (2008). Motivation and self-regulated learning: Theory, research, and applications. New York: Taylor \& Francis.

Schunk, D.H., \& Zimmerman, B.J. (2006).Competence and control beliefs: Distinguishing the means and ends. In P.A. Alexander \& P.H. Winne (Eds.), Handbook of educational psychology (2nd ed., pp. 349-367). Mahwah, NJ: Erlbaum.

Seidel, J., \& Kelle, U. (1995). Different functions of coding in the analysis of textual data. In U. Kelle (Ed.), Computer-aided qualitative data analysis: Theory, methods, and practice (pp. 52-61). Thousand Oaks, CA: Sage.

Senemoğlu, N., \& Özçelik, D.A. (1989). Öğretmen adaylarına "öğretmenlik bilgisi" kazandırma bakımından fen-edebiyat ve eğitim fakültelerinin etkililiği [Effectiveness of faculties of education and faculties of arts and science in terms of providing teaching knowledge for prospective teachers]. Çağdaş Eğitim Dergisi [Journal of Contemporary Education], 142, $18-21$.

Shores, M. L., \& Smith, T. (2010), Attribution in Mathematics: A Review of Literature. School Science and Mathematics, 110, 24-30.

Tashakkori, A., \&Teddlie, C. (1998). Mixed methodology: Combining qualitative and quantitative approaches. Thousand Oaks, CA: Sage.

Wang, M.C. (1983). Development and consequences of students' sense of personal control. In J.M. Levien \& M.C. Wang (Eds.), Teacher and student perceptions: Implication for learning (pp. 213-247).Hillsdale, NJ: Erlbaum.

Weiner, B. (1979). A theory of motivation for some classroom experiences. Journal of Educational Psychology, 71, 3-25.

Weiner, B. (1985). An attributional theory of achievement motivation and emotion. Psychological Review, 92, 548-573. 
Weiner, B. (1992). Human motivation. Metaphors, Theories, and Research. Newbury Park, CA: Sage Publications.

Weiner, B. (2000). Intrapersonal and interpersonal theories of motivation from an attributional perspective. Educational Psychology Review, 12, 1-14.

Weiner, B. (2004).Attribution theory revisited: Transforming cultural plurality into theoretical unity. In D. M. McInerney \& S. Van Etten (Eds.), Big theories revisited (pp. 13-29). Greenwich, CT: Information Age Publishing.

Weiner, B., \& Peter, N. (1973). A cognitive-developmental analysis of achievement and moral judgments. Developmental Psychology, 9, 290-309.

Weiner, B., Frieze, I., Kukla, A., Reed, L., Rest, S., Rosenbaum, R. (1971). Perceiving the causes of success and failure. In E. E. Jones, D. Kanouse, H. H. Kelley, R. E. Nisbett, S. Valins, \& B. Weiner. Attribution: Perceiving the Causes of Behavior. Morristown, NJ.: General Learning Press.

Williams, S. (1991). Models of limit held by college calculus students. Journal for Research in Mathematics Education, 22(3), 219236.

Wilson, T. D., Damiani, M., \& Shelton, N. (2002). Improving the academic performance of college students with brief attributional interventions. In J. Aronson (Ed.), Improving academic achievement: Impact of psychological factors on education (pp. 89-108). New York: Academic Press.

Wong, P. T. P., \& Weiner, B. (1981). When people ask "why" questions, and the heuristics of attributional search. Journal of Personality and Social Psychology, 40, 650-663. 